\title{
The Role of Brand Equity and Perceived Value for Stimulating Purchase Intention in B2C e-Commerce Web Sites
}

\author{
Mustafa Emre Civelek ${ }^{a}$, Adnan Veysel Ertemel ${ }^{b}$
}

\begin{abstract}
This paper attempts to clarify the underlying mechanism behind purchase decision on $\mathrm{B} 2 \mathrm{C}$ e-commerce web sites. Research question of the study is to investigate the interaction between brand equity, perceived value and purchase intention in $\mathrm{B2C} e$ commerce context by specifically questioning the direct and indirect effects within the process. Firstly, the hypotheses in the conceptual model were tested. Secondly, post-hoc analyses were conducted to clarify the mediator roles of perceived value and brand loyalty. Sub dimensions of brand equity are namely brand awareness, brand association and brand loyalty. As a result of post-hoc analyses, partial mediator roles of perceived value and brand loyalty have been proved for each variable. But the most prominent finding of this study is the disappearing of the relations between brand associations and brand loyalty and between perceived value and purchase intention after including all the variables into the global research model. This result, particularly, supported the joint mediator roles of perceived value and brand loyalty.
\end{abstract}

Keywords: Brand Equity, Perceived Value, Purchase Intention

JEL: M10, L81, M31

$\begin{array}{ll}\text { Received } & : 16 \text { August } 2018 \\ \text { Revised } & : 22 \text { October } 2018 \\ \text { Accepted } & : \text { 22 November } 2018 \\ \text { Type } & : \text { Research }\end{array}$

\section{Introduction}

With the advent of Internet, the nature and process of brand-consumer relationship changed to a great extent. E-commerce is a typical example to that phenomenon that has become a common practice. $\mathrm{E}$ Commerce is defined as the use of Internet technology to conduct business transactions with others. Internet technology revolutionized the way businesses conduct transactions both in business-to-business (B2B) and business-to-consumer (B2C) context. B2C e-commerce has special importance that it enables trading at individual level across the world by providing easier, cheaper and faster methods to conduct transactions. The Internet penetration continuously increases every year (Worldbank, 2018). Therefore, there is great business potential in B2C area (Wagner \& Monk, 2008). The most important aspect of doing business in B2C area is the performance of web site (Jansen \& James, 2002; Qin, 2010). And also, one of the important factors in assessing performance of a $\mathrm{B} 2 \mathrm{C}$ e-commerce web site is its ability, as a brand, to influence and create favorable perceptions in the mind of their target customers (Schegg \& Stangl, 2017). This can only happen by building strong brand equity on web site level. One of the fundamental aspects of branding strategy is adding value to a product or service. In value-adding process, brand equity is the most fundamental concept that a brand has to account for. For a B2C e-commerce web site to become successful, it has to turn the brand equity into sales revenue. Hence, customer purchase decision plays a critical role in the process. This paper attempts to clarify the underlying mechanism behind purchase decision on $\mathrm{B} 2 \mathrm{C}$ e-commerce web sites.

a Asst. Prof., PhD., Istanbul Commerce University, Faculty of Business Administration, Istanbul, Turkiye, ecivelek@ticaret.edu.tr (ORCID ID: 0000-0002-2847-5126)

b Asst. Prof., PhD., Istanbul Commerce University, Faculty of Business Administration, Istanbul, Turkiye, avertemel@ticaret.edu.tr (ORCID ID: 0000-0002-5028-1096) 
Research question of the study is to investigate the interaction between brand equity, perceived value and purchase intention in B2C e-commerce context by specifically questioning the direct and indirect effects within the process. Most prominent contribution of this study is that, in the extant literature, the dimensions included in the conceptual model of this research have not been tested before in such a hybrid structure. Therefore, the role of perceived value in the relationship among the sub-dimensions of brand equity and purchase intention has been clarified.

\section{Conceptual Background}

\subsection{Brand Equity}

Brand Equity can be defined as "the differential effect that brand knowledge has on consumer response to the marketing of that brand". Combined with the brand stimuli, this effect leads to a strong brand preference (Cobb-Walgren et al., 1995). Brand equity can also lead to consumer evaluations of brand extensions (Aaker, 1991) and price insensitivity (Erdem et al. 2002). Different scholars have different viewpoints in demystifying the brand equity concept. Some scholars attempt to explain it by looking from financial perspective and calculating profit margin that stems from brand itself (Simon \& Sullivan, 1993). On the other hand, some scholars look from customer perceived value perspective. In this view, brands' products leads to consumers' biased dispositions toward the brand (Biel, 1997). Keller (2001) argues that in-depth knowledge of a specific brand causes more favorable reactions to the marketing activities. As brand equity increases, consumer perceptions are influenced favourably for the brand and this leads to consumer preferences and purchase intentions towards the brand (Cobb-Walgren, Ruble \& Donthu, 1995). As shown in Figure 1, this paper proposes a sequential research model that aims to test the relationship between brand equity, perceived value and purchase intention as well as the relationship between the sub-dimensions of brand equity. Current literature includes many studies aiming to identify and validate the sub-dimensions of brand equity including brand associations, brand awareness, brand loyalty, trust, social image, commitment (Kumar et al., 2013; Buil et al., 2008). This study incorporates the three sub-dimensions of Aaker's (1991) brand equity concept, which are brand awareness, brand associations and brand loyalty.

\subsubsection{Brand Awareness}

Brand awareness can be defined as "the ability of a potential buyer to recognize or recall that a brand is a member of a certain product category (Aaker, 1991). Brand awareness can take place in varying levels (Tasci \& Kozak, 2006). At one extreme is lack of awareness where consumers have no knowledge about a brand. As the brand awareness starts to be formed, brand recognition and brand recall takes place consecutively (Keller, 1993). Brand recognition occurs when consumers are exposed to brand-oriented messages. Brand recall can be defined as the consumers' ability to retrieve brand-related information from their memory. The ultimate stage of brand awareness, namely high awareness, refers to making automatic connection between the brand and its products without any reminder from others. Brand awareness provides added value to a brand which creates familiarity, and hence commitment from consumers (Aaker, 1991).

\subsubsection{Brand Association}

Brand association is a critical part of brand equity concept as documented in existing literature (Keller, 1993). A brand association is defined as anything linked to the brand in the memory (Aaker, 1991). Brand associations can be classified into three categories, namely; attributes benefits and attitudes (Keller, 1993; Qu et. al., 2011). Brand attributes are features of a brand that constitute tangible offerings. Attributes can be product related or non-product related (i.e. price, packaging, user imagery, imagery). Benefits are associated values of the brand. Benefits could be functional, experiential or symbolic. Brand attitudes are overall evaluations made by the consumers about the brand. Brand associations influence brand choices and can provide competitive advantage (Aaker, 1991; Keller, 1993). 


\subsubsection{Brand Loyalty}

Brand loyalty can be defined as a deeply held commitment to rebuy a product or service despite situational influences that may cause brand swathing behavior (Oliver, 1997). Hence it can be viewed as the degree to which consumers are committed to a brand. This commitment can take place in the form of inner attitudes reflected by biases towards a specific brand. It can also be externally exhibited behavior like repeat purchases ultimately leading to brand loyalty (Odin et al., 2001). It takes less time and money to keep existing customers especially when consumers are loyal to a brand. Grover et al. (1992) pinpointed that loyal customers exhibit more favorable responses to a brand stimuli than non-loyal customers. Brand loyalty, therefore, is an important aspect of brand equity that enables the brands to cut marketing costs.

\subsection{Perceived Value}

Perceived value is based on equity theory. According to equity theory, the net difference between what consumers get as opposed to what they sacrifice (in the form of money, time consumption, consumer stress) is the basis for consumer evaluation of what's fair or deserved (benefit) (Oliver et al., 1988; Bolton \& Lemon, 1999). Accordingly, outcomes are compared to sacrifices and rewards received. Therefore, perceived value can be defined as an overall assessment of the risks and rewards related with the brand and its products. This theory is especially crucial in the e-commerce context, where it is important for the brands to establish a permanent relationship with their consumers. Consumers generally benchmark the ratio of brand outcome by comparing to alternative offerings. Due to the fierce online competition and the relative ease of instant comparisons, customer value has become more critical in retaining customer loyalty (Yang \& Peterson, 2004).

\subsection{Purchase Intention}

Behavioral intention is the most influential predictor of behavior according to the theory of planned behavior (Ajzen, 1991). Also, utility theory states that consumers are willing to reach maximum utility in their purchase decisions (Henderson \& Quandt, 1958). Scholars use purchase intention to represent the actual behavior (Lin, 2006). Therefore, in this study, we used purchase intention as an antecedent variable in predicting actual behavior. Previous research also suggests that perceived value has positive influence on purchase intention (Dodds et al., 1991; Monroe, 1990). Therefore, purchase intention was used as an antecedent variable in predicting actual behavior.

\section{Research Model and Hypothesis Development}

\subsection{The Relationship between Brand Awareness and Brand Association}

Being unaware of brand bring about diminishing brand equity. Brand awareness, hence, precedes other brand equity constructs. Among these, Villarejo et al. (2005) argues that increased brand awareness gives rise to better brand association. Thus, in the light of the existing literature, we hypothesize that:

$\mathbf{H}_{1}$ : Brand Awareness has a positive effect on Brand Association.

\subsection{The Relationship between Brand Association and Brand Loyalty}

Some previous studies shed light to the relationship between brand associations and brand loyalty. Park et al. (1994) argued that brand associations have a strong positive influence on brand loyalty. This implies that consumers become more loyal if brand associations are positive. Some other studies found out that positive associations lead to positive responses to various marketing programs (Yoo et al., 2000; Park et al., 1994) ultimately helping to the formation of a loyal customer base (Gladden \& Funk, 2004). Thus, in the light of the existing literature, we hypothesize that:

$\mathbf{H}_{2}$ : Brand Association has a positive effect on Brand Loyalty. 


\subsection{The Relationship between Brand Association and Perceived Value}

Brand associations represent what the customers think the brand has to offer. Associations encompass consumers' attitudes to and overall evaluations about the brand. Previous studies have demonstrated that, positive brand associations lead to better perceived value of the brand (Brown \& Dacin, 1997; Shapiro, 1983). Thus, in the light of the existing literature, we hypothesize that:

$\mathbf{H}_{3}$ : Brand Association has a positive effect on Perceived Value.

\subsection{The Relationship between Perceived Value and Brand Loyalty}

Previous studies have pointed out customer perceived value as a major precedent of customer loyalty. In e-commerce context, high-perceived value is of the main factors for customer patronage (Chen \& Dubinsky, 2003; Parasuraman \& Grewal, 2000). Yang and Peterson (2004) have confirmed that customer value exerts a positive effect on customer loyalty. Thus, in the light of the existing literature, we hypothesize that:

$\mathbf{H}_{4}$ : Perceived Value has a positive effect on Brand Loyalty.

\subsection{The Relationship between Perceived Value and Purchase Intention}

As demonstrated by many scholars, increased perceived value leads to intention to purchase in ecommerce by eliminating the need to look for alternatives (Wang, 2008; Kim \& Gupta, 2009; Dodds et.al, 1991; Parasuraman \& Grewal, 2000). Thus, in the light of the existing literature, we hypothesize that:

$\mathbf{H}_{5}$ : Perceived Value has a positive effect on Purchase Intention.

\subsection{The Relationship between Brand Loyalty and Purchase Intention}

Prior research have found out that e-commerce site loyalty influences purchase intention implying loyalty as a predictor of online purchase intention (Kamariah \& Salwani, 2005; Wang et al., 2006). It can be said that a customer who has loyalty to an e-commerce site is also highly likely to have a strong behavioral intention to make purchases on that site. Thus, in the light of the existing literature, we hypothesize that:

$\mathbf{H}_{6}$ : Brand Loyalty has a positive effect on Purchase Intention.

The conceptual research model showed in Figure 1 aims to explore the sequential relationship among brand equity, perceived value and purchase intention.

Figure 1. Conceptual Research Model

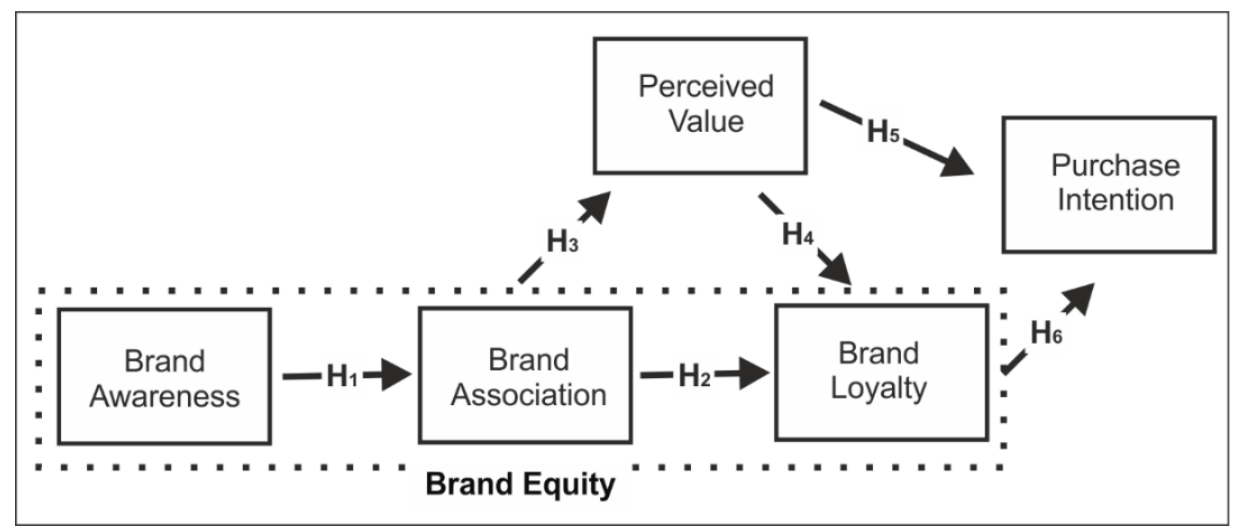

\section{Research Methodology}

This study was a quantitative cross-sectional research. Five-point ordinal Likert scale; ranging from strongly disagree to strongly agree was used in the survey. Firstly, the reliability and validity of the scales were determined. Subsequently, structural equation modeling method was used to test the hypotheses. Structural equation modeling which is a multi-variable statistical method was used to clarifying direct and 
indirect relationships among the constructs in a single model (Civelek, 2018a). This method is taking measurement errors into consideration (Byrne, 2010). Therefore it is superior to multiple regression analysis. AMOS and SPSS statistics programs were used for analyses. Additionally, as post-hoc analysis, mediator analyses were conducted according to Baron and Kenny method (Baron \& Kenny, 1986).

\subsection{Measures and Sampling}

The scales adopted from prior studies were used to measure the dimensions. The scales adopted by Han et al. (2015) from prior studies were used to measure brand awareness (4 items). Similarly, scales adopted Jiang et al. (2015) were used to measure customer loyalty (6 items) and perceived value (5 items). And finally scales adopted from Chen and Teng (2013) were used to measure purchase intention ( 3 items). More than 500 distributed, 464 valid questionnaires were gathered from prominent cities (Ankara, İstanbul, Bursa, İzmir, Antalya, Adana, Gaziantep, Samsun) throughout Turkey by using convenience sampling method and voluntary response and by using face to face method. 240 of the respondents are male and 224 are female. Population of research covers the e-commerce web site users living in Turkey.

\subsection{Construct Validity and Reliability}

The confirmatory factor analysis was conducted for remaining 20 items after the data purification process. This analysis was performed so as to determine convergent validity of the constructs (Anderson \& Gerbing, 1988). CFA model fit indices results have adequate fit: $\chi 2 / D F=1.654, C F I=0.945, I F I=0.946, R M S E A=$ 0.053. $\chi 2$ is The Likelihood Ratio Chi-Square Test. The analysis shows the conformity of the acquired model and the initial model. A X2/DF ratio is under the threshold level of 3 (Bagozzi \& Yi, 1990). Furthermore, other fit indices exceeded their recommended thresholds.

Table 1. Confirmatory Factor Analysis Results

\begin{tabular}{|c|c|c|c|}
\hline Variables & Items & $\begin{array}{l}\text { Standardized } \\
\text { Factor Loads }\end{array}$ & $\begin{array}{l}\text { Unstandardized } \\
\text { Factor Loads }\end{array}$ \\
\hline \multirow{5}{*}{ Brand Loyalty } & Bly0641 & 0.580 & 1 \\
\hline & Bly0136 & 0.833 & 1.547 \\
\hline & Bly0439 & 0.629 & 1.223 \\
\hline & Bly0237 & 0.861 & 1.507 \\
\hline & Bly0338 & 0.720 & 1.422 \\
\hline \multirow{3}{*}{ Brand Awareness } & Baw0404 & 0.501 & 1 \\
\hline & Baw0101 & 0.849 & 1.638 \\
\hline & Baw0202 & 0.895 & 1.629 \\
\hline \multirow{5}{*}{ Perceived Value } & Pva0434 & 0.695 & 1 \\
\hline & Pva0535 & 0.717 & 1.020 \\
\hline & Pva0333 & 0.511 & 0.844 \\
\hline & Pva0131 & 0.527 & 0.782 \\
\hline & Pva0232 & 0.677 & 1.029 \\
\hline \multirow{3}{*}{ Purchase Intention } & Pin0142 & 0.733 & 1 \\
\hline & Pin0344 & 0.837 & 0.901 \\
\hline & Pin0243 & 0.847 & 1.536 \\
\hline \multirow{4}{*}{ Brand Association } & Bas0408 & 0.594 & 1 \\
\hline & Bas0206 & 0.613 & 1.008 \\
\hline & Bas0610 & 0.615 & 0.946 \\
\hline & Bas0509 & 0.586 & 1.007 \\
\hline
\end{tabular}


As shown in Table 1, confirmatory factor analysis resulted as the standardized factor loads of each item are larger than 0.5 and significant. These results determined the convergent validity of the scales. So as to assess discriminant validity, the square roots of average variance extracted values were calculated and compared with correlation values of the constructs in the same column.

In Table 2, the diagonals demonstrate the square root of AVE value of each variable. And as shown in Table 2, the square roots of average variance extracted values are beyond the correlation values in each column (Byrne, 2010). Reliability of each construct individually calculated. Composite reliability and Cronbach $\alpha$ values are beyond the threshold level (i.e. 0.7) (Fornell \& Larcker, 1981). Composite reliabilities, average variance extracted values, Cronbach $\alpha$ values, means, standard deviations and Pearson correlation coefficients of the constructs are shown in Table 2.

Table 2. Construct Descriptives, Correlation and Reliability

\begin{tabular}{l|ccccc}
\hline Variables & 1 & 2 & 3 & 4 & 5 \\
\hline 1.Brand Awareness & $(.768)$ & & & & \\
2.Brand Association & $.285^{*}$ & $(.602)$ & & & \\
3.Brand Loyalty & $.342^{*}$ & $.368^{*}$ & $(.733)$ & & \\
4.Perceived Value & $.364^{*}$ & $.386^{*}$ & $.521^{*}$ & $(.632)$ & \\
5.Purchase Intention & $.369^{*}$ & $.249^{*}$ & $.590^{*}$ & $.414^{*}$ & $(.807)$ \\
\hline Composite reliability & .804 & .695 & .850 & .765 & .848 \\
\hline Average variance ext. & .591 & .363 & .537 & .399 & .652 \\
\hline Cronbach $\alpha$ & .784 & .694 & .846 & .785 & .844 \\
\hline Mean & 4.18 & 3.52 & 3.82 & 3.74 & 3.98 \\
\hline Standard Deviation & 0.71 & 0.73 & 0.74 & 0.65 & 0.75 \\
\hline *p $<0.01$ & & & & \\
Note: Diagonals show the square root of AVEs.
\end{tabular}

\subsection{Test of Hypotheses}

The structural model has been analyzed by using covariance based structural equation modelling (CBSEM). Maximum likelihood, which is the default estimation method of CB-SEM, was used. The absolute and relative goodness-of-fit indices of the model were evaluated. In this analysis, the absolute and relative indices were used. The absolute goodness of fit indices are the root mean square error of approximation (RMSEA) and the $\chi 2$ goodness of fit statistic. The relative goodness of fit indices are the comparative fit index (CFI) and the incremental fit index (IFI).

Table 3. Hypotheses Test Results

\begin{tabular}{l|c|c}
\hline Relationships & $\begin{array}{c}\text { Standardized } \\
\text { Coefficients }\end{array}$ & $\begin{array}{c}\text { Unstandardized } \\
\text { Coefficients }\end{array}$ \\
\hline Brand Awareness $\rightarrow$ Brand Association & $0.328^{*}$ & $0.460^{*}$ \\
Brand Association $\rightarrow$ Brand Loyalty & 0.148 & 0.123 \\
Brand Association $\rightarrow$ Perceived Value & $0.608^{*}$ & $0.585^{*}$ \\
Perceived Value $\rightarrow$ Brand Loyalty & $0.614^{*}$ & $0.530^{*}$ \\
Perceived Value $\rightarrow$ Purchase Intention & 0.094 & 0.102 \\
Brand Loyalty $\rightarrow$ Purchase Intention & $0.587^{*}$ & $0.740^{*}$ \\
${ }^{*} p<0.05$ & \multicolumn{2}{|l}{}
\end{tabular}


As shown in Figure 2, structural model fit indices adequately indicate model fit. $\chi 2$ /DF value is 1.601 and within threshold levels (i.e. between 0 and 2). CFI and IFI are 0.948 and 0.949 respectively. RMSEA is 0.051 . The results indicated that the model has adequate fit (Civelek, 2018b). As shown in Table $3, \mathrm{H}_{1}, \mathrm{H}_{3}, \mathrm{H}_{4}$ and $\mathrm{H}_{6}$ are supported and $\mathrm{H}_{2}$ and $\mathrm{H}_{5}$ are not supported. These results may stems from mediator effect of variable. Therefore post-hoc analyses were needed to clarify the matter. These results of the tests indicate a positive and significant relationship between brand awareness and brand association, between brand association and perceived value and between perceived value and brand loyalty and between brand loyalty and purchase intention.

Figure 2. Results of SEM Analysis

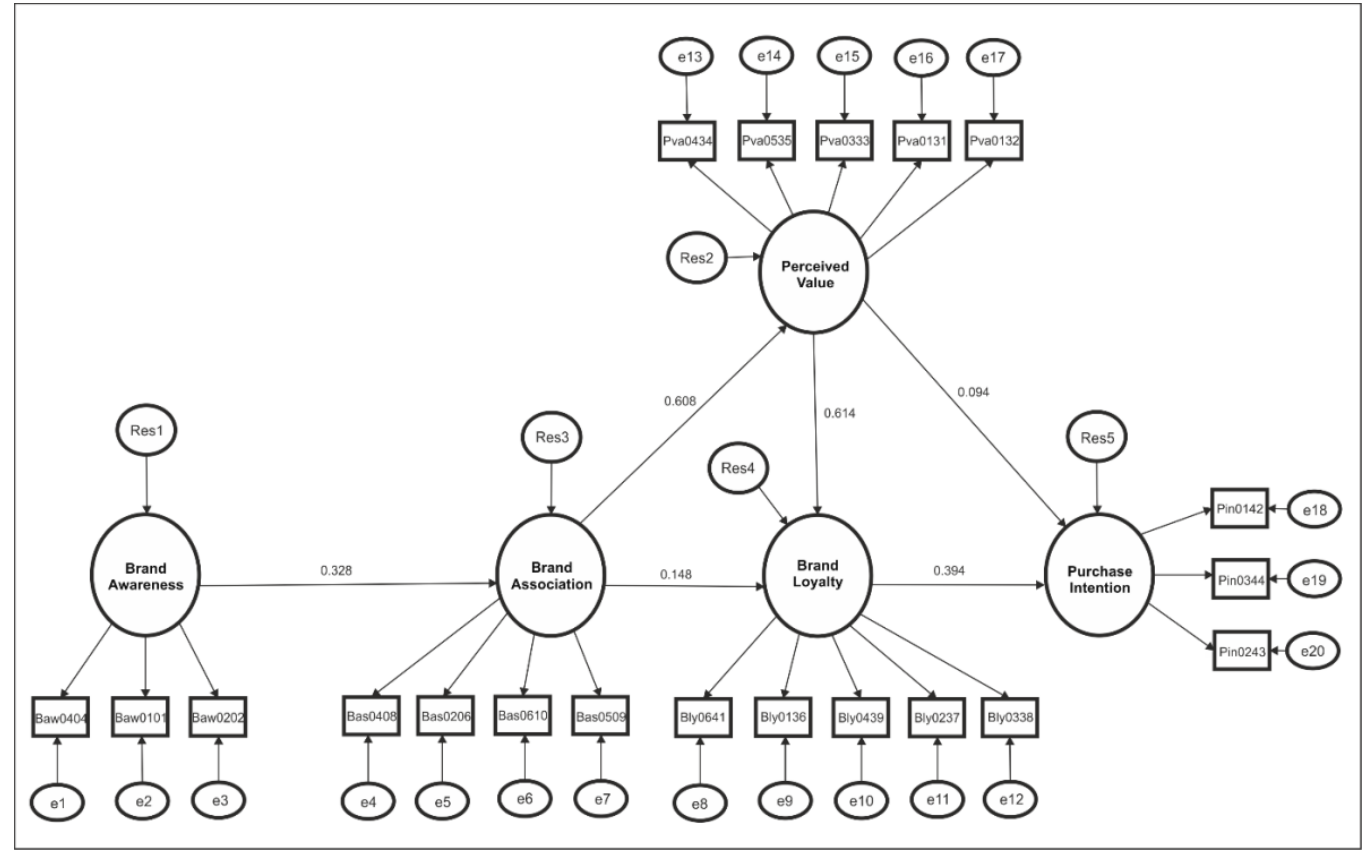

Note: $\mathrm{X} 2 / \mathrm{DF}=1.601, \mathrm{CFI}=0.948, \mathrm{IFI}=0.949, \mathrm{RMSEA}=0.051$

And also, according to the results, post-hoc analyses were conducted for investigation mediator roles of perceived value and brand loyalty. For the post-hoc analyses Baron and Kenny method was applied. For this reason two additional hypotheses were suggested. In the light of the path analysis results, we hypothesize that:

$\mathbf{H}_{7}$ : Perceived Value (PVA) plays mediator role in the relation between Brand Association (BAS) and Brand Loyalty (BLY).

$\mathbf{H}_{8}$ : Brand Loyalty (BLY) plays mediator role in the relation between Perceived Value (PVA) and Purchase Intention (PIN).

The mediator analyses were conducted according to Baron and Kenny method (Baron \& Kenny, 1986). According to this method, firstly, correlations among the variables should be verified (Baron \& Kenny, 1986). Correlations among the variables are significant as shown in the Table 2 . To test $\mathrm{H}_{7}$ below 3 models developed:

$$
\begin{aligned}
& \text { Model A1: BLY }=\beta 0+\beta 1 \cdot B A S+€ \\
& \text { Model A2: PVA }=\beta 0+\beta 2 \cdot B A S+€ \\
& \text { Model A3: BLY }=\beta 0+\beta 1 \cdot B A S+\beta 2 \cdot P V A+€
\end{aligned}
$$


The Role of Brand Equity and Perceived Value for Stimulating Purchase Intention in B2C e-Commerce Web Sites

Table 4. Perceived Value $\left(\mathrm{H}_{7}\right)$ Mediator Hypothesis Test Results

\begin{tabular}{l|cccc}
\hline Relationships & Model A1 & Model A2 & Model A3 & $\begin{array}{c}\text { Research } \\
\text { Model }\end{array}$ \\
\hline Brand Association (BAS) $\rightarrow$ Brand Loyalty (BLY) & $0.368^{*}$ & & $0.196^{*}$ & 0.148 \\
Brand Association (BAS) $\rightarrow$ Perceived Value (PVA) & & $0.386^{*}$ & & $0.608^{*}$ \\
Perceived Value (PVA) $\rightarrow$ Brand Loyalty (BLY) & & & $0.445^{*}$ & $0.614^{*}$ \\
\hline
\end{tabular}

Note: Path coefficients are standardized

$*_{p}<0.01$

To test $\mathrm{H}_{8}$ below 3 models developed:

Model B1: PIN $=\beta 0+\beta 1 . P V A+€$

Model $B 2: B L Y=\beta 0+\beta 2 \cdot P V A+€$

Model B3: PIN $=\beta 0+\beta 1 . P V A+\beta 2 \cdot B L Y+€$

Table 5. Brand Loyalty $\left(\mathrm{H}_{8}\right)$ mediator hypothesis test results

\begin{tabular}{l|cccc}
\hline Relationships & Model 1 & Model 2 & Model 3 & Research Model \\
\hline Perceived Value (PVA) $\rightarrow$ Purchase Intention (PIN) & $0.414^{*}$ & & $0.146^{* *}$ & 0.094 \\
Perceived Value (PVA) $\rightarrow$ Brand Loyalty (BLY) & & $0.521^{*}$ & & 0.614 \\
Brand Loyalty (BLY) $\rightarrow$ Purchase Intention (PIN) & & & $0.514^{*}$ & 0.587 \\
\hline
\end{tabular}

Note: Path coefficients are standardized

$* p<0.01 ; \quad * * p<0.05$

As shown in Table $4 \mathrm{H}_{7}$ is partially supported. Because after PVA was included into the model relationship between BAS and BLY considerable decreased but not turned to insignificant. As shown in Table $5 \mathrm{H}_{8}$ is partially supported. Because after BLY was included into the model relationship between PVA and PIN considerable decrease but not turned to insignificant. According to post-hoc models it can be said that PVA partially mediates the relationship between BAS and BLY and also BLY partially mediates the relationship between PVA and PIN. However, in the research model, these relationships became insignificant. After including all construct into the model and taking measurement errors into consideration these relations disappeared completely.

\section{Conclusion}

This research provides an important contribution to the existing literature by explaining the relationship among brand equity, perceived value and purchase intention. After conducting post hoc analyses, partial mediator roles of perceived value and brand loyalty have been proved. But the most prominent finding of this study is the disappearing of the relation between brand association and brand loyalty and between perceived value and purchase intention after including all the variables into the global research model. This result, particularly, supported the joint mediator roles of perceived value and brand loyalty in the big picture.

The findings of this research is of particular importance in that, broadening to the previous research, this study has taken in consideration brand loyalty into the e-commerce model as proposed by Chen \& Dubinsky (2003) that embodies perceived value and purchase intention, and found out that brand loyalty has a partial mediator effect. Similarly, this study revealed that the relationship between brand association and brand loyalty does not have quite direct effect like it's suggested by previous literature (Keller, 2001), but rather, it's partially mediated by perceived value. As a result of the research, important scientific clues were reached regarding the relationship among brand equity, perceived value and purchase intention. 
Having analyzed the results, we can conclude that, in e-commerce B2C web site context, brand associations is not merely adequate to create brand loyalty, but brands should rather be focusing on maximizing perceived value which can concisely be defined as "what's got in return for what is sacrificed". On the other hand, it can be concluded that perceived value is not a direct precedent of purchase intention. But rather, brand loyalty has a partial mediator effect in purchase decision.

Having analyzed the results, we can conclude that, in their efforts to increase perceived value and brand equity dimensions, namely, brand awareness, brand association and brand loyalty, e-commerce website managers should stop trying to improve each dimension on its own but rather should improve all of them simultaneously. Managers should take all these concepts into account in a nested and interrelated manner. Only with such a strategy managers bring about an increase in perceived value and brand equity as a whole ultimately stimulating purchase intention. Consequently, this paper may pave the way for future researches on this topic.

\section{References}

Aaker, D. (1991). Managing brand equity: Capitalizing on the value of a brand name. New York: The Free Press.

Ajzen, I. (1991). The theory of planned behavior. Organizational Behavior and Human Decision Processes, 50(2), 179211.

Anderson, J., \& Gerbing, D. (1988). Structural equation modelling in practice: A review and recommended two-step approach. Psychological Bulletin.

Bagozzi, R. P., \& Yi, Y. (1990). Assessing method variance in multitrait-multimethod matrices: The case of self-reported affect and perceptions at work. Journal of Applied Psychology, 75(1), 547-560.

Baron, R., \& Kenny, D. (1986). The moderator - Mediator variable distinction in social phychological research. Journal of Personality and Social Phychology, 51(6), 1173-1182.

Biel, A. L. (1997). Discovering brand magic: The hardness of the softer side of branding. International Journal of Advertising, 16(3), 199-210.

Bolton, R. N., \& Lemon, K. N. (1999). A dynamic model of customers' usage of services: Usage as an antecedent and consequence of satisfaction. Journal of Marketing Research, 36(2), 171-186.

Brown, D. (1997). The company and the product: Corporate associations and consumer product responses. Journal of Marketing, 61(1), 68-84.

Buil, I., Chernatony, L., \& Martínez, E. (2008). A cross-national validation of the consumer-based brand equity scale. Journal of Product \& Brand Management, 17(6), 384-392.

Byrne, B. M. (2010). Structural equation modeling with AMOS. New York: Routledge Taylor \& Francis Group.

Chen, Z., \& Dubinsky, A. J. (2003). A conceptual model of perceived customer value in e-commerce: A preliminary investigation. Psychology \& Marketing, 20(4), 323-347.

Chen, M. Y., \& Teng, C. I. (2013). A comprehensive model of the effects of online store image on purchase intention in an e-commerce environment. Electronic Commerce Research, 13(1), 1-23.

Civelek, M. (2018a). Essentials of structural equation modeling. Lincoln: University of Nebraska Lincoln-Zea Books.

Civelek, M. (2018b). Yapısal eşitlik modellemesi metodolojisi. İstanbul: Beta.

Cobb-Walgren, C. J., Ruble, C. A., \& Donthu, N. (1995). Brand equity, brand preference, and purchase intent. Journal of Advertising, 24(3), 25-40.

Dodds, W. B., \& Grewal, D. (1991). Effect of price, brand and store information on buyer's product evaluation. Journal of Marketing Research, 28(3), 307-319.

Erdem, T., Swait, J., \& Louviere, J. (2002). The impact of brand credibility on consumer price sensitivity. International Journal of Research in Marketing, 19(1), 1-19.

Fornell, C., \& Larcker, D. (1981). Evaluating structural equation models with unobservable variables and measurement error. Journal of Marketing Research, 18(1), 39-50.

Gladden, J. M., Funk, D. C., Rosner, S. R., \& Shropshire, K. L. (2004). The business of sports. Jones and Bartlett Publishing, Sudburry, 194. 
Grover, R., \& Srinivasan, V. (1992). Evaluating the multiple effects of retail promotions on brand loyal and brand switching segments. Journal of Marketing Research, 29(1), 76-89.

Han, S., Nguyen, B., \& Lee, T. (2015). Consumer-based chain restaurant brand equity, brand reputation. International Journal of Hospitality Management, 50(1), 84-93.

Henderson, J. M., \& Quandt, R. E. (1958). Microeconomic theory: A mathematical approach. New York: McGraw-Hill.

Jansen, E., \& James, V. (2002). NetLingo: The internet dictionary. Ojai: NetLingo Incorporated.

Jiang, L., Jun, M., \& Yang, Z. (2016). Customer-perceived value and loyalty: How do key service quality dimensions matter in the context of B2C e-commerce? Service Business, 10(2), 301-317.

Kamariah, N., \& Salwani, S. (2005). Determinants of online shopping intention. Proceedings of International Conference on E-Commerce, 167-172.

Keller, K. L. (1993). Conceptualizing, measuring, and managing customer-based brand equity. The Journal of Marketing, $57(1), 1-22$.

Keller, K. L. (2001). Building customer-based brand equity: A blueprint for creating strong brands.

Kim, P. (1990). A perspective on brands. Journal of Consumer Marketing, 7(4), 63-67.

Kim, H. W., \& Gupta, S. (2009) A comparison of purchase decision calculus between potential and repeat customers of an online store. Decision Support Systems, 47, 477-487.

Kumar, R. S., Dash, S., \& Purwar, P. C. (2013). The nature and antecedents of brand equity and its dimensions. Marketing Intelligence \& Planning, 31(2), 141-159.

Lin, L. Y., \& Chen, C. S. (2006). The influence of the country-of-origin image, product knowledge and product involvement on consumer purchase decisions: An empirical study of insurance and catering services in Taiwan. Journal of consumer Marketing, 23(5), 248-265.

Monroe, K. B., \& Krishman, R. (1985). The effects of price on subjective product evaluations. In J. Jacoby \& J. Olson (Eds.), Perceived quality (pp. $209-232$ ). Lexington, MA: Lexington Books.

Oliver, R. L. (1997). Satisfaction: A behavioral perspective on the consumer. Routledge.

Oliver, R. L., \& DeSarbo, W. S. (1988). Response determinants in satisfaction judgments. Journal of consumer research, 14(4), 495-507.

Odin, Y., Odin, N., \& Valette-Florence, P. (2001). Conceptual and operational aspects of brand loyalty: An empirical investigation. Journal of Business Research, 53(2), 75-84.

Parasuraman, A., \& Grewal, D. (2000). The impact of technology on the quality-value-loyalty chain: A research agenda. Journal of Marketing Science, 28, 168-174.

Park, C. S, \& Srinivasan, V. (1994). A survey-based method for measuring and understanding brand equity and its extendibility. Journal of Marketing Research, 31(2), 271-288.

Qu, H., Kim, L. H., \& Im, H. H. (2011). A model of destination branding: Integrating the concepts of the branding and destination image. Tourism Management, 32(3), 465-476

Qin, Z. (2010). Introduction to e-commerce. Berlin: Springer.

Schegg, R., \& Stangl, B. (2017). Information and communication technologies in tourism 2017. Rome: Springer International Publishing.

Shapiro, C. (1983). Premiums for high quality products as returns to reputations. The Quarterly Journal of Economics, 98(4), 1253-1265.

Simon, C. J., \& Sullivan, M. W. (1993). The measurement and determinants of brand equity: A financial approach. Marketing Science, 12(1), 28-52.

Tasci, A. D., \& Kozak, M. (2006). Destination brands vs destination images: Do we know what we mean? Journal of Vacation Marketing, 12(4), 299-317.

Uncles, M., \& Gilles, L. (1997). Editorial, special issue on loyalty. International Journal of Research in Marketing, 14, 399404.

Villarejo-Ramos, A. F., \& Sanchez-Franco, M. J. (2005). The impact of marketing communication and price promotion on brand equity. Journal of Brand Management, 12(6), 431-444.

Wang, H. C., Pallister, J. G., \& Foxall, G. R. (2006). Innovativeness and involvement as determinants of website loyalty: II. Determinants of consumer loyalty in B2C e-commerce. Technovation, 26(12), 1366-1373. 
Wang, Y.S. (2008). Assessing e-commerce systems success: A respecification and validation of the DeLone and McLean model of IS success. Information Systems Journal, 18, 529-557.

Wagner, B., \& Monk, E. (2008). Enterprise resource planning. Boston: Cengage Learning.

Yang, Z., \& Peterson, R. T. (2004). Customer perceived value, satisfaction, and loyalty: The role of switching costs. Psychology \& Marketing, 21(10), 799-822.

Yoon, E., Guffey, H. J., \& Kijewski, V. (1993). The effects of information and company reputation on intentions to buy a business service. Journal of Business Research, 27(3), 215-277.

Yoo, B., Donthu, N., \& Lee, S. (2000). An examination of selected marketing mix elements and brand equity. Journal of the Academy of Marketing Science, 28, 195-211. 
This Page Intentionally Left Blank 